\title{
Being a student at the Faculty of Sports and Physical Education in COVID- 19 Pandemic times - A moment in life
}

\author{
Cerasela DOMOKOS ${ }^{1 *}$, Martin DOMOKOS ${ }^{2 *}$, Silvia Nicoleta MIRICĂ ${ }^{1}$, Cristian NEGREA ${ }^{3}$, \\ Eugen BOTA4, Adrian NAGEL ${ }^{5}$
}

\begin{abstract}
Introduction: The COVID-19 Pandemic started in December 2019 in China and it affected millions of people, forcing them to radically change their lifestyle. Aim: Thus, the idea of starting a study that evaluates the effects of the online media transfer on the life routine of PESF-WUT students was outlined, becoming the purpose of the present paper. Material and methods: This study consisted of analyzing a developed questionnaire applied on a study group of 334 students from PESF -WUT, which evaluated 3 aspects of our students' life: the educational aspect, physical activity and leisure time. Results: The results revealed that COVID-19 Pandemic was a major life changing factor for our students, affecting all aspects of their daily routines. The evaluation of behavior regarding physical activity revealed that this component of our students' life is of great importance in both the educational and leisure aspects of life. Conclusion: The study revealed that face to face, interpersonal contact has a great impact for both educational performance and the psychological and social aspect, by keeping the level of motivation at high standards. Last but not least, physical activity performed even in unusual conditions, such as Pandemic lockdowns has a great influence on stress management.
\end{abstract}

Key words: COVID-19 pandemic, physical activity, online education system, leisure time

\section{Rezumat}

Introducere: Pandemia COVID-19 începută în decembrie 2019 în China a afectat milioane de oameni, forțându-i să își schimbe radical stilul de viață. Scop: Astfel, s-a conturat ideea de a începe un studiu care evaluează efectele transferului în mediul online al multor activități asupra modului de viață a studenților de la FEFS-UVT, în această perioadă. Material si metoda: Studiul a constat în analiza răspunsurilor la un chestionar aplicat unui număr de 334 studenți FEFS-UVT care a analizat 3 aspecte ale vieții acestora: aspectul educațional, activitatea fizică și timpul liber. Rezultate: Rezultatele au arătat că pandemia de COVID-19 a fost un factor care a determinat schimbări majore în viața studenților noștri care afectează toate aspectele activităților zilnice: rutina educațională, aspectul social și activitatea sportivă. Evaluarea comportamentului în ceea ce privește activitatea fizică a arătat că această componentă are o importanță majoră atât în ceea ce privește activitatea didactică cât și în timpul liber. Concluzie: Studiul a relevat faptul că interacțiunea față în față, are o importanță deosebită atât pentru atingerea performanței universitare, cât și pentru aspectul psihologic și social, prin păstrarea nivelului de motivație la standard înalte. Activitatea fizică desfășurată chiar și în condiții neobișnuite, cum ar fi izolarea în timpul Pandemiei, are o influență mare asupra gestionării stresului.

Cuvinte cheie: pandemia COVID-19, activitate fizică, educație online, timp liber

\footnotetext{
${ }^{1}$ Lecturer, MD, PhD, West University of Timisoara, Romania, e-mail: nicoleta.mirica@e-uvt.ro

${ }^{1}$ Research Assistant, PhD student, West University of Timisoara, Romania

${ }^{2}$ Associate Professor, PhD, West University of Timisoara, Romania

${ }^{3}$ Lecturer PhD, West University of Timisoara, Romania

${ }^{4}$ Associate Professor, PhD, West University of Timisoara, Romania

${ }^{5}$ Associate Professor, PhD, West University of Timisoara, Romania

*The authors contributed equally to the article
} 


\section{Introduction}

The COVID-19 Pandemic started in December 2019 in Wuhan, China affecting millions of people, and forcing them to change their lifestyle radically. In only 5 months, the infection spread rapidly; thus on $29^{\text {th }}$ of May there were over 5 million cases according to the World Health Organization (WHO and world-meter information $[1,2]$.

Its continuous development also affected Romania that reported over 18,000 cases, ranking us on the $38^{\text {th }}$ place worldwide [1]. This unusual medical situation determined the authorities to implement measures of great security for all population categories such as the state of emergency for 60 days declared in March and April 2020 by the Romanian Authorities [3,4]. Within the Education field, the immediate effect of the Pandemic lockdown was the closing of face to face education at every level and the online transfer of the entire educational process. This determined a great change in the daily routine of all the involved actors: teaching staff and students, respectively.

According to our educational domain as Faculty of Sports and Physical Education (FSPE), our teaching activities related to the faculty specializations: Sports and Physical Education and Physical Therapy and Special Motor Skills, involve a lot of physical activity and interpersonal interaction in both individual and group sports, as well as rehabilitation activities that take place in indoor and outdoor conditions. So, the COVID-19 Pandemic situation forced us to adapt the educational process to online methods of teaching. Moreover, according to the law during the state of emergency $[3,5,6]$ it was mandatory to stay inside as much as possible. So, this also affected the training of all our students who are registered as performance athletes in their specific sports branch. Also, this new educational transfer in online media determined a lot of discussions within the FSPE student groups and student-teacher groups, and we became aware that this new challenge, we all were exposed to, has an impact on the students' daily routine.

Regarding all these facts, the idea of starting a study that evaluates the effects of the online teaching system on the life routine of FSPE students was outlined becoming the purpose of the present paper.

\section{Material and methods}

The study has been conducted at the Faculty of Sports and Physical Education from the West University of Timisoara during April and May 2020. The study group consisted of 334 students in the
FSPE both from bachelor's and master's programs. The methodology of the study included the elaboration of a questionnaire with 40 questions to evaluate 3 aspects of the students' life during COVID- 19 Pandemic lockdown. The sections of the questionnaire referred to:

- the aspects regarding the educational process, where we intended to evaluate aspects of the online teaching methodology regarding practical activities and the involvement of the students within the online process. The emphasis was especially on teaching specific practical activities performed in online classes, according to the faculty specific physical activity curricula for practical activities. We were also interested in the student-teacher communication aspect and, moreover, in the impediments which occurred within the online teaching process and our students' attendance at online practical classes. Also, we evaluated the level of students' motivation in performing the practical activities online, and in their appreciation regarding the intensity level of the classes.

- the aspects regarding the physical activity performed by the students outside school classes. We evaluated aspects regarding the type of activity, number of training sessions, aspects related to the students 'sportive shape, intensity level of their physical activity outside school classes, and driving factors for doing extra school planned practical physical activities.

- the aspects regarding leisure issues during the COVID-19 Pandemic. We were interested in the type of leisure activities our students are interested in during this period, the involvement in domestic activities and satisfaction level of our students that are in the elite athlete category regarding the fact that their specific sportive activity was also impeded during lockdown.

The questionnaire was conceived also using the online tools (Google forms and Classroom platforms). The students were informed on the purpose of the study and were asked to respond as accurately as possible to the proposed questions.

Also, at the beginning of the questionnaire, the students were informed that the processing of personal data complies with the legislation in force and the data provided by answering the questionnaire will be used only for scientific research purposes. The questionnaire continued with the individual agreement statement regarding the participation within the study.

The data were collected in real time and were further analyzed by the research team.

The results were expressed in percentage values and statistical analysis was performed by using statistical functions from Office Excel 2016. The Pearson correlation coefficient (r) was calculated. 


\section{Results}

Data analysis revealed the following group characterization: there was found an important disproportion between male and female numbers according to the total group number of the quiz respondents. Almost twice of the respondents were males ( $63 \%$ males vs. $36.4 \%$ females). The students age group consisted of 4 subgroups 18-20, 21-23, $24-26$ and $>26$ years, respectively. Over $84 \%$ of the students were categorized within the groups 18-20 and 21-23. Over $95 \%$ of the respondents were attending the bachelor program compared to the ones from the master program. The distribution regarding the percentage of the respondents according to the study year of the students revealed a highly significant interest among the students in the first and the second years compared to the ones in the third year of the bachelor program $(47.2 \%$ students in the 1 st year vs. $20.5 \%$ student in the third year). Also, the respondents from the Physical Education and Sports program represented the majority, i.e. over $50 \%$ of the subjects compared to the rest of the study programs.

The first section of the questionnaire referred to the aspects regarding the online participation in the practical activities. Analyzing the data, we found that over $52 \%$ of the respondents declared that, during the lockdown they spent about $75 \%$ of school-time participating in the online classes. $25.2 \%$ of the respondents declared that they had full attendance. And only a small percentage, less than $10 \%$ from the entire study group, reported under 25\% participation in online classes. From those who participated in the online classes, over $90 \%$ declared that they participated in at least 50\% of the classes as shown in figure 1.

When asked about the reason that impaired their participation in the online practical activities, the obtained percentage showed the great majority (60\%) claimed that their work schedule, also affected by the lockdown, contributed to this low attendance.

The second reason mentioned referred to internet connection impairments (50\%), followed very closely by the impossibility to connect to the used platforms. However, only $10 \%$ declared that the reason why they did not participated was the fact that they were unable to accomplish their tasks, and $15 \%$ of the students declared that they did not want to participate

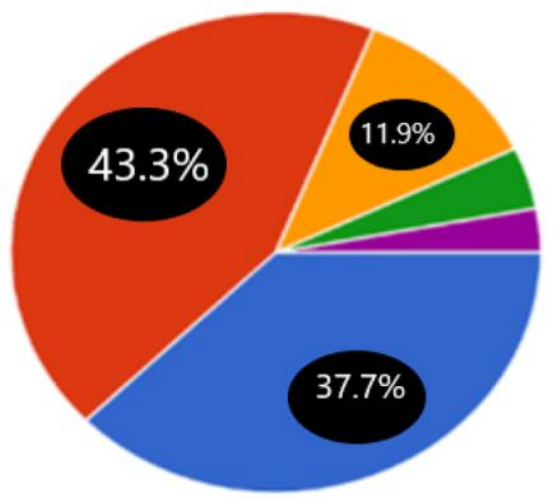

Figure 1. Attendance percentage to online classes courses: blue $=100 \%$, red $=75 \%$, yellow $=50 \%$, green $=$ $25 \%$, purple= under $25 \%$

A fact of great importance in this study was to evaluate the motivation level of our students to participate in the online educational process determined by the Pandemic situation. Thus, figure 2 reveals that over $50 \%$ of our students were motivated (50.7\%). 31.2\% responded that their motivation level was extremely low and only $8.6 \%$ included themselves in the highly motivated category.

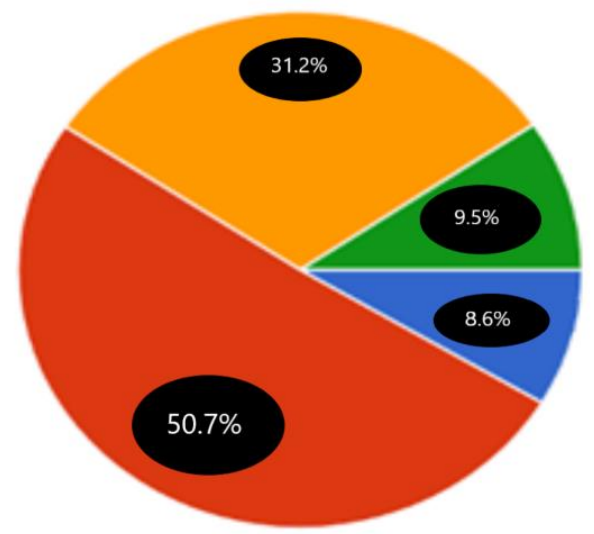

Figure 2. Motivation level to participate in the online courses: red $=$ motivated category, yellow- very low motivated category, glue- highly motivated category and green- unmotivated category

Very interesting results were found when analyzing the question regarding the audio-video communication. Over $50 \%$ of the students declared that they didn't open their audio-video communication channels (cameras and microphones), mostly (30\% of cases) because they considered it unimportant to be seen or heard during the classes. Even so, 93\% of those who participated in the online classes declared that they respected the tasks they were asked for during the 
classes. And only 7\% did not accomplished them. The main reasons for not accomplishing the tasks were the lack of space in over $50 \%$ of the cases, followed by the lack of motivation in over $40 \%$ of the cases. In a small percentage, they indicated health problems in $20 \%$ of the cases. Also, a great minority didn't want to actively participate in the class $1<10 \%$ of the cases, and they considered the activity useless in about $15 \%$ of the cases, respectively. Regarding the online practical activities, $46 \%$ of the students appreciated the online teaching method to be a good one compared to only $7.7 \%$ of the entire study group (referred as $100 \%$ ) who were completely unsatisfied about it.

The second section of the form was referred to the students' physical activity within the pandemic period. The great majority of the students (73.6\%) considered that the intensity level of the physical activity was lower during the online classes compared to the classical live classes. When asked to indicate the main factor that determine their physical activity, the great majority, i.e. $66 \%$ of the students, pointed out the maintenance of their physical training, and about 50\% the improvement of their health status. For a small percentage of about $10 \%$, the practicing of physical activity has a social dimension, by implication of their group of friends in it. $43.6 \%$ of the students declared that they practice physical activity with a frequency of 3 5 sessions/week and almost 40\% declared that they practice physical activity daily, as shown in figure 3. This is due to the fact that only $31.2 \%$ are elite athletes who practice sports at a high level of performance.

Correlating the personal appreciation of physical condition with the frequency of training sessions, we found a weak positive correlation $(r=+0.31)$ (table 1).

As expected, a higher training frequency leads to a better physical condition. Unexpectedly, $100 \%$ of the subjects who trained very rarely $(\leq 1-2 /$ month) declared a good or very good physical condition, but they represent only $1.2 \%$ of the study group.

The last section of the questionnaire referred to leisure time. $34.7 \%$ of the students responded that their free time reduced substantially. One third of the students indicated that there wasn't any modification regarding the free time, and over 50\% indicated a reduction of the free time by $25-50 \%$.

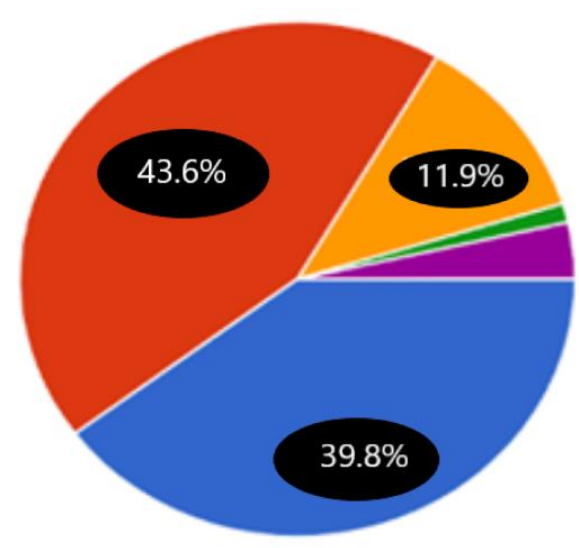

Figure 3. The frequency of physical activity sessions (red: 3-5 sessions/week, dark blue: daily practice, yellow1-2 times/week, green - 1-2 times/months, purple - very rare, light blue-never)

\begin{tabular}{|c|c|c|c|c|}
\hline $\begin{array}{l}\text { Training } \\
\text { sessions }\end{array}$ & $\begin{array}{c}\text { Daily } \\
\text { (41.9\% of } \\
\text { cases ) }\end{array}$ & $\begin{array}{c}3-5 / w . \\
(44 \% \\
\text { of } \\
\text { cases) }\end{array}$ & $\begin{array}{c}1-2 / w \\
(12.57 \% \\
\text { of cases) }\end{array}$ & $\begin{array}{c}1-2 / \mathrm{m} \\
(1,2 \% \\
\text { of cases) }\end{array}$ \\
\hline $\begin{array}{l}\text { Excelent } \\
\text { shape }\end{array}$ & 15.71 & 3.38 & 2.38 & 0.00 \\
\hline $\begin{array}{l}\text { Very } \\
\text { good } \\
\text { shape } \\
\end{array}$ & 47.14 & 29.73 & 14.29 & 75.00 \\
\hline $\begin{array}{l}\text { Good } \\
\text { shape }\end{array}$ & 36.43 & 65.54 & 71.43 & 25.00 \\
\hline $\begin{array}{l}\text { Weak } \\
\text { shape }\end{array}$ & 0.71 & 1.35 & 11.90 & 0.00 \\
\hline Total & 100.00 & 100.00 & 100.00 & 100.00 \\
\hline $\begin{array}{l}\text { Table I. } \\
\text { condition } \\
\text { w.= week, }\end{array}$ & $\begin{array}{l}\text { requency } \\
\text { relation } \\
=\text { month }\end{array}$ & traini & sessions & physical \\
\hline
\end{tabular}

Over $65 \%$ indicated physical activity as the main leisure activity. By analyzing the data, about $40 \%$ spent this time mostly in the online media, and less than $30 \%$ spent most of this time reading. We were also interested in domestic activities, and over $60 \%$ were involved in cleaning, cooking and shopping. Other activities that involved the participation of our students, but to a lesser extent, were walking the dog, cutting the grass and gardening, and some repairing activities. Being at home, over $75 \%$ of our students indicated that they were involved in domestic chores at least once a day, most of them (53.1\%) being involved even several times a day. A great interest of the study referred to the students' physical activity performed outside classes. Thus, all the subjects indicated that they also practice physical activity outside classes, and 71.8\% indicated that the last training session took place within the previous day. Still, over $90 \%$ indicated that they missed the specific activities that are 
normally scheduled within the curricula of the faculty. Over $70 \%$ of them indicated on a scale from 1 to 10 (where 1 was scaled as "didn't miss the specific activity at all" and 10 as "missed the specific activity very much") that they highly and very highly missed the specific activity (the most indicated numbers being from 8-10).

The level of motivation was moderate, $49 \%$ indicating that they were motivated. Only $26.7 \%$ of the respondents declared that their level of motivation regarding practicing the physical activity in their leisure time was low. Biking, roller skating and weightlifting exercises occupied the first position in the top of the leisure physical activity (about $50 \%$ of the cases), followed by stretching, walking and aerobic activities. Practicing these kinds of physical activities helped $81 \%$ of the respondents to deal with the stress induced by the pandemic period. Even so, only $15.7 \%$ lost up to $2.5 \mathrm{~kg}$ body weight within this period, and about $40 \%$ gained between $1-5 \mathrm{~kg}$. Only $29.1 \%$ indicated the maintenance of their pre-Pandemic weight.

Considering that our study group included elite athletes as well, an aspect regarding the satisfaction level referred to the fact that their specific sportive activity was also impeded; the study revealed that over 55\% presented a low level of satisfaction. Because they couldn't train as before the Pandemic lockdown (figure 4).

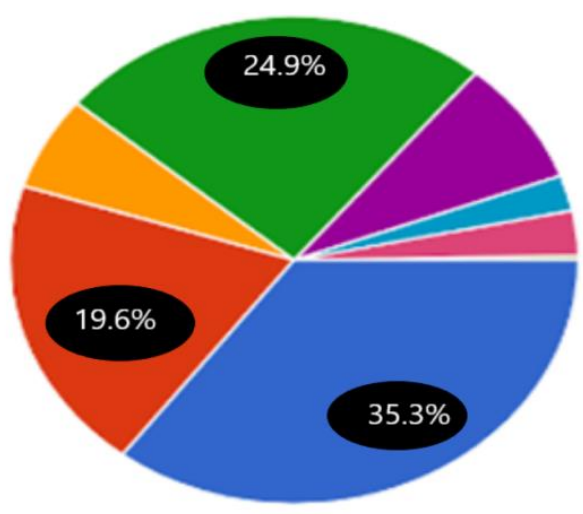

Figure 4. Self-appreciation status of performance athletes regarding the impossibility to train in the same conditions as before the Pandemic lockdown period. (dark blue- unpleased, red- bored, dark green-out of sportive shape, orange-tired, purple -irritability, light blue -pleased, pink- acceptance, light green - low selfesteem)

\section{Discussions}

The COVID-19 pandemic has affected all the domains of activity. Also, students have been affected in different ways, not only concerning their course of study, but also with regard to their daily life and program [5].
Physical activity is mandatory and offers a new opportunity to engage in practicing exercises of different duration and intensity in order to maintain the health and mental status [7]. Practicing physical activity should not be impaired by a specific place to perform it. During the COVID -19 Pandemic lockdown period, we all had to adapt our daily routine to the new conditions. The present study results revealed that our students were affected by the pandemic lockdown. First, they had to adjust to the new online teaching methods. As the OECD report (2020) highlights, there could be situations when access to digital devices and internet may not be achieved by all students [7]. For example, 95\% of the students in Switzerland, Norway, and Austria have a computer to use for their schoolwork, but only $34 \%$ have it in Indonesia [8]. In our study, we showed that over $75 \%$ percent of our students have accessibility and participated to the online classes. Analyzing the data, we found that there was a reduction in the students' motivation in actively and constantly participating in the online classes. Still, the great majority of the students adapted and participated in the classes, ranking the educational teaching method to be a good one. Agrawal \& Kaushik (2020) showed that their participants in the study considered that the online sessions helped them to change the monotony and also that the presented material was easy to access. They also indicated a good level of motivation to read on the online topics, which was helpful for reducing the COVID Pandemic stress and to have a peaceful sleep [9]. The students in this study were from the medical field, so, in this case, the online teaching demonstrated helpful for theoretical topics. In the case of our students, the specific of their activity is physical activity. According to this specific character of our faculty, it is understandable why our results revealed a lower level regarding our students' motivation. Daniel (2020) points out the fact that during COVID-19 a lot of students could suffer long-term disadvantages, compared to those who studied in the classical manner, and he underlines that vocational education and training needs special attention [5]. Coming back to our study, the results can confirm this idea. The fact that almost half of our students did not communicate openly, by shutting down the audio-video channels, could contribute to their lost in motivation, especially that they indicated that face to face contact with their professors and friends is one of the most important factors which are mostly missed in this period.

Regarding the fact that our faculty specific activity is a physical one, our students prefer the "normal teaching method". Indeed, it could be difficult to perform some sportive activities online and to 
respect all the specifics, but exercise could also be accomplished at home, as our results revealed. Strength-training, weightlifting and also callisthenic exercises may help us reduce the negative effects of stress and anxiety [6]. Our results revealed that our students who performed physical activity in class or outside the educational process were helped in order to overcome the pandemic induced stress. Domestic chores also involve a level of physical activity and, by analyzing the responses, we found that a great number of our respondents were involved in domestic activities at least 1 time /day. Social distancing affects the wellbeing of all population not only of the members of at-risk populations categories [10]. The social distancing affected our study group as well. Their responses regarding leisure time revealed that, in this age category, the fact that they were unable to meet their social groups affected their spirit greatly and determined them to indicate this factor as one of the most important factors that affected their life during the pandemic lockdown.

The present study was a data collection one, regarding a specific period of time - i.e. the Pandemic lockdown, which determined some limitations in interpreting the data. Because we didn't have reference data from the period that preceded the Pandemic lockdown, we were not able to compare the obtained data regarding the online teaching process with data on the "face to face" teaching method. Also, because in the present study we didn't collect the data regarding the students' attendance and level of motivation in participating to practical activities within the curricula, we also were not able to provide a comparison between pre-Pandemic and Pandemic periods of the 20192020 school year. Also, we didn't apply validated questionnaires regarding the evaluation of stress management or motivation. So, our results indicating that physical activity helped our students to better cope within this period are based only on the individual appreciation of our subjects. Also, we only focused on aspects regarding the attendance and implication of the students in participating in the online practical activity, which is only one aspect characterizing the teaching process. In further research we will provide a more detailed analysis also by evaluating other specific aspects of the online teaching process.

Social interaction is possible by using online media and communication technology provided by the mobile phones and devices [11].

\section{Conclusion}

The COVID-19 Pandemic was a life changing factor for our students affecting all aspects of their daily routine. The evaluation of the behavior regarding physical activity revealed that this component of our students' life is of great importance in both the educational and leisure aspects of life. Moreover, the study revealed that face to face interpersonal contact has a great importance for both the educational performance, and psychological and social aspect, by keeping the level of motivation at high levels. Last but not least, the physical activity performed even in unusual conditions, such as Pandemic lockdowns, has a great influence on stress management.

\section{References}

1. https://www.worldometers.info/coronavirus (accessed in 29.05.2020)

2. WHO - Coronavirus disease (COVID-19) Situation Report 129,28.05.2020.

3. https://www.who.int/docs/defaultsource/coronaviruse/si tuation-reports/20200528-covid19sitrep129.pdf?sfvrsn $=5 \mathrm{~b} 1548802$ (accessed in 29.05.2020)

4. Romanian Presidency, DECRET nr. 195 din 16 martie 2020 privind instituirea stării de urgență pe teritoriul României, Official Monitor nr. 212/16.03.2020

5. Romanian Presidency, DECRET nr. 240 din 15 aprilie 2020 privind instituirea stării de urgență pe teritoriul României, Official Monitor nr. 311/14.04.2020

6. Daniel S. J. (2020). Education and the COVID-19 pandemic. Prospects, 1-6. Advance online publication.

7. https://medicine.umich.edu/dept/psychiatry/michiganpsychiatry-resources-covid-19/your-lifestyle/importancephysical-activity-exercise-during-covid-19-pandemic (accessed in 30.05.2020)

8. http://www.oecd.org/pisa/ (accessed in 30.05.2020)

9. Chick R. C., Clifton, G. T., Peace, K. M., Propper, B. W., Hale, D. F., Alseidi A. A., Vreeland T. J. (2020). Using Technology to Maintain the Education of Residents During the COVID-19 Pandemic. Journal of surgical education, S19317204(20)30084-2. Advance online publication., in press.

10. https://www.sciencedirect.com/science/article/pii/S1931 720420300842?via\%3Dihub (accesed in 30.05.2020)

11. Agarwal, S., \& Kaushik, J. S. (2020). Student's Perception of Online Learning during COVID Pandemic. Indian journal of pediatrics, 1. Advance online publication.

12. https://pubmed.ncbi.nlm.nih.gov/32385779/(accesed in 30.05.2020)

13. Abel T, McQueen D. The COVID-19 pandemic calls for spatial distancing and social closeness: not for social distancing!. International Journal of Public Health, 202065(3), 231.

14. Mesa Vieira C., Franco O.H., Restrepo C.G., Abel T. (2020), COVID-19: The forgotten priorities of the pandemic, Maturities, vol. 136, 38-41. 